Research Article

\title{
Assessment of Pharmacognostic (Physical, Chemical and Analytical) Parameters \& In-Vitro Antioxidant Potential of Tephrosia purpurea (L.) Pers.
}

\author{
Gaurav Kumar Sharma*, Sarita Sharma, Pankaj Chasta, Kaushal K. Chandrul \\ Department of Pharmacy, Mewar University, Gangrar-312901, Dist- Chittorgarh (Rajasthan), India. \\ *Corresponding author's E-mail: garvsharma2050@gmail.com
}

Received: 11-09-2020; Revised: 24-11-2020; Accepted: 30-11-2020; Published on: 15-12-2020. \begin{abstract}
The aim of the present study was to investigate the different pharmacognostic parameters and to evaluate the antioxidant activity of the plant Tephrosia purpurea (L.) Pers. by the DPPH method. Aqueous, ethanol, petroleum ether and chloroform extracts of the leaves were prepared and subjected to phytochemical screening which revealed the presence of carbohydrates, proteins, steroids, terpenoids, glycosides, flavonoids, and lipids, tannins and phenolic compounds. The antioxidant activity of the Tephrosia purpurea (L.) Pers. was also determined by the DPPH method using ascorbic acid as standard. The results obtained in this study support the use of Tephrosia purpurea (L.) Pers. in herbal medicine and it can be used as a potent antioxidant in the treatment of many diseases resulting from more reactive oxygen species (ROS) presence.
\end{abstract}

Keywords: Herbal medicine, Tephrosia purpurea (L.) Pers., Antioxidant, DPPH.

QUICK RESPONSE CODE $\rightarrow$

DOI:

10.47583/ijpsrr.2020.v65i02.016

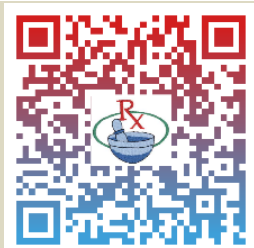

DOI link: http://dx.doi.org/10.47583/ijpsrr.2020.v65i02.016

\section{INTRODUCTION}

$\mathrm{n}$ recent times natural products are becoming an integral part of human health care system, because there is a now popular concern over toxicity and side effects of modern drugs. There is also a realization that natural medicines are safer and allopathic drugs are often ineffective in several aliments. Medicinal plants existed even before human being made their appearance on the earth. Man's existence on this earth has been made possible only because of the vital role played by plant kingdom in sustaining his life. Since the down of civilization, in addition to food crops, man cultivated herbs for his medicinal needs ${ }^{1}$.

Over the most recent couple of decades, there has been an exponential development in the field of home-grown medication. It is getting popularized in developing and developed countries owing to its natural origin and lesser side effects. In excess of 700 mono and polyherbal arrangements as decoction, tincture, tablets, and containers from in excess of 100 plants are in clinical use ${ }^{2}$.

Tephrosia purpurea (L.) Pers. is a medicinal plant belonging to the family Leguminosae commonly known in Sanskrit as Sharapunkha is a highly branched, suberect, herbaceous perennial herb.

As indicated by Ayurveda writing this plant has additionally given the name of "Sarwawranvishapaka" which implies that it has the property of recuperating a wide range of wounds. It is a significant segment of certain arrangements, for example, Tephroli and Yakrifit utilized for liver issue. In Ayurvedic arrangement of medication different pieces of this plant are utilized as solution for impotency, asthma, looseness of the bowels, gonorrhea, stiffness, ulcer and urinary issue. The plant has been claimed to cure diseases of kidney, liver spleen, heart and blood. The dried herb is powerful as tonic purgative, diuretics and deobstruents. It is likewise utilized in the treatment of bronchitis, bilious febrile assault, bubbles, pimples and draining heaps.

The present study was carried out to evaluate the antioxidant efficacy of aqueous, ethanol, pet. ether and chloroform extract of Tephrosia purpurea (L.) Pers., which helps in the development of new, novel drugs.
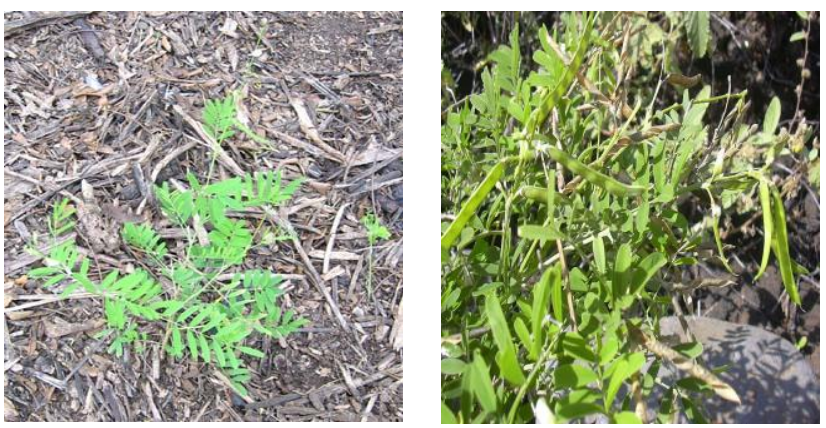

Tephrosia purpurea (L.) Pers.

\section{MATERIALS AND METHODS}

\section{Chemicals and Solvents}

Solvents, chemicals and reagents of analytical grade or best possible grade supplied by Ranbaxy Labs, Himedia Laboratories Pvt, Ltd., S.D. Fine Chemicals Ltd. India. 


\section{Collection of plant sample}

The plant of Tephrosia purpurea (L.) Pers. was acquired from Local market Jaipur. Sample was shade dried at room temperature and powdered mechanically and passed through a sieve \# 40 .

\section{Preliminary phytochemical investigation}

\section{Extraction}

The air-dried pieces of the plants were powdered and separated with $95 \%$ ethanol, chloroform, pet ether (400600 ) and fluid dissolvable frameworks by hot permeation technique by utilizing Soxhlet contraption gathering at a controlled temperature. After complete extraction, marc was squeezed to gather the micelle, blended in with the substance of RBF, separated and thought to get the concentrate. The shading and consistency of the concentrate were noted. This concentrate was additionally exposed to phytochemical examination ${ }^{3}$.

\section{Determination of Physical Constants}

Preliminary extraction of individual plant material Tephrosia purpurea (L.) Pers. is carried out with 95\% ethanol using soxhlet extractor and then concentrated. The extract obtained is subjected for preliminary physicochemical investigation such as loss on drying (LOD), ash values, extractive values and fluorescent analysis.

\section{Loss On Drying}

Misfortune on drying is the loss of mass communicated as percent $\mathrm{w} / \mathrm{w}$. The test for misfortune on drying decides both water and unpredictable issue in the unrefined medication. Dampness is an inescapable segment of unrefined medication, which must be dispensed with beyond what many would consider possible.

An accurately weighed quantity of about $5 \mathrm{~g}$ of powdered drug was taken in a tared porcelain dish. The powder was distributed evenly. The porcelain dish kept open in vacuum broiler and the example was dried at a temperature $110^{\circ} \mathrm{C}$ for $2 \mathrm{~h}$ until a consistent weight was recorded. Then it was cooled in desiccators to room temperature, weighed and recorded. \% Loss on drying was considered using the following equation.

$\%$ Loss on drying = Loss of weight in the sample/ weight of sample $X 100$

\section{Ash Values}

Debris esteems are useful in deciding the quality and virtue of an unrefined medication, particularly in the powdered structure. The goal of ashing vegetable medications is to expel all hints of natural issues, which may somehow or another meddle in a logical assurance.

On cremation, rough medications ordinarily leave debris as a rule comprising of carbonates, phosphates, and silicates of sodium, potassium, calcium, and magnesium. The complete debris of a rough medication mirrors the consideration taken in its planning. A higher cut off of corrosive insoluble debris is forced, particularly in situations where silica might be available or when the calcium oxalate substance of the medication is exceptionally high.

\section{Total ash value}

Accurately weighed 2 to $3 \mathrm{~g}$ of the powdered drug (Tephrosia purpurea (L.) Pers.) in a tared silica crucible, incinerated at a temperature not exceeding $4500 \mathrm{C}$ for $4 \mathrm{~h}$, until free from carbon, cooled and weighed. Calculate the percentage of ash with reference to air-dried drug powder using following formula.

$\%$ Total Ash Value = Wt. of total ash/ Wt. of crude drug x100

\section{Water soluble ash value}

The ash obtained above is with $25 \mathrm{ml}$ of water. Separated and gathered the insoluble issue on an ashless channel paper, washed with boiling water and lighted in a tared pot at a temperature not surpassing $4500 \mathrm{C}$ for $4 \mathrm{~h}$. Cooled in a desiccator and gauged. weight of insoluble issue is subtracted from a complete load of debris, the distinction in weight spoke to the heaviness of water-solvent debris. The level of water-dissolvable debris is determined concerning the air-dried medication utilizing the accompanying recipe.

$\%$ water dissolvable debris esteem $=\mathrm{Wt}$. of Total debris $\mathrm{Wt}$. of water-insoluble debris X $100 / \mathrm{Wt}$. of Crude Drug Taken

\section{Corrosive insoluble debris esteem}

Heated up the debris for 5 min with $25 \mathrm{ml}$ of $2 \mathrm{M} \mathrm{HCl}$. Separated and gathered the insoluble issue on an ashless channel paper, washed with high temp water and touched off in a tared pot at a temperature not surpassing $4500 \mathrm{C}$ for $4 \mathrm{~h}$. Cooled in a desiccator and gauged.

Calculate the percentage of acid insoluble ash with reference to the air-dried drug using following formula.

$$
\% \text { Acid Insoluble Ash value }=\frac{\text { Wt. of acid insoluble ash }}{\text { Wt. of crude drug taken }} \times 100
$$

\section{Extractive Values}

\section{Alcohol soluble extractive value}

Macerated $5 \mathrm{gm}$ precisely weighed coarsely powdered medication with $100 \mathrm{ml}$ of liquor $(90 \% \mathrm{v} / \mathrm{v})$ in a stoppered flagon for $24 \mathrm{~h}$, shaking as often as possible during the initial $6 \mathrm{~h}$. Sifted quickly through channel paper playing it safe against inordinate loss of liquor.

Evaporated $25 \mathrm{ml}$ of alcoholic extract to dryness in a tarred dish and weighed it. Percentage $\mathrm{w} / \mathrm{w}$ of alcohol soluble extractive is calculated with reference to the air-dried drug.

\section{Water soluble extractive value}

Above mentioned procedure is followed using chloroform water I.P. instead of alcohol ${ }^{4-9}$. 


\section{Fluorescence Analysis of Drug}

Many crude drugs show the fluorescence when the sample is exposed to UV radiation. Evaluation of crude drugs based on fluorescence in daylight is not much used, as it is usually unreliable due to the weakness of the fluorescent effect. Fluorescence lights are fitted with reasonable channels, which take out unmistakable radiation from the light and transmit UV radiation of positive frequency. A few unrefined medications show trademark fluorescence helpful for their assessment ${ }^{10}$.

\section{Qualitative Chemical Tests}

Synthetic tests are led on the concentrate of the plant test and furthermore of the powdered type of the plant tests utilizing standard techniques.

\section{Tests for Carbohydrates}

The readiness of test arrangement: The test arrangement was set up by dissolving the test extricates with water. At that point, it was hydrolyzed with 1 volume of $2 \mathrm{~N} \mathrm{HCl}$ and exposed to the following compound tests.

\section{Molish's test (General test)}

To 2-3 $\mathrm{ml}$ watery concentrate included barely any drops of $\alpha$-naphthol arrangement in liquor, shaken and included concentrated $\mathrm{H}_{2} \mathrm{SO}_{4}$ from sides of the test tube was watched for a violet ring at the intersection of two fluids.

\section{Fehling's test}

$1 \mathrm{ml}$ Fehling's A and $1 \mathrm{ml}$ Fehling's B arrangements were blended and bubbled for one moment. An equivalent volume of test arrangement was included. Warmed in bubbling water shower for 5-10 min was watched for yellow, at that point block red encourage.

\section{Benedict's test}

An equivalent volume of Benedict's reagent and test arrangement in the test tube were blended. This is warmed in a bubbling water shower for $5 \mathrm{~min}$. The arrangement may seem green, yellow or red relying upon the measure of decreasing sugar present in test arrangement.

\section{Barfoed's test}

An equivalent volume of Barfoed's reagent and test arrangement were included. Warmed for 1-2 min, in bubbling water shower and cooled. This is watched for red encouragement.

\section{Cobalt-chloride test}

$3 \mathrm{ml}$ of test arrangement was blended in with $2 \mathrm{ml}$ cobalt chloride, bubbled and cooled. Included $\mathrm{FeCl}_{3}$ drops $\mathrm{NaOH}$ arrangement. Arrangement watched for greenish blue (glucose), purplish (Fructose) or upper layer greenish-blue and lower layer purplish (Mixture of glucose and fructose).

\section{Tests for Non-Reducing Sugars}

The test arrangement does not give a reaction to Fehling's and Benedict's tests.

\section{The tannic basic analysis for starch}

With $20 \%$ tannic corrosive, the test arrangement was watched for accelerate.

\section{Tests for Proteins}

The readiness of Test Solution: The test arrangement was set up by dissolving the concentrate in water.

\section{Biuret test (General test)}

To $3 \mathrm{ml}$ Test Solution included $4 \% \mathrm{NaOH}$ and a couple of drops of $1 \% \mathrm{CuSO}_{4}$ arrangement watched for violet or pink shading.

\section{Million's test (for proteins)}

Blended $3 \mathrm{ml}$ Test Solution with $5 \mathrm{ml}$ Million's reagent, the white encourage got. Hasten warmed turns to block red or encourage disintegrates giving red shading was watched.

\section{Xanthoprotein test (For protein-containing tyrosine or tryptophan)}

Blended $3 \mathrm{ml}$ Test Solution with $1 \mathrm{ml}$ concentrated $\mathrm{H}_{2} \mathrm{SO}_{4}$ watched for white encourage.

\section{Precipitation test}

The test arrangement gave white colloidal acceleration with the accompanying reagents: Absolute liquor, 5\% $\mathrm{HgCl}_{2}$ arrangement, $5 \% \mathrm{CuSO}_{4}$ arrangement, $5 \%$ lead acetic acid derivation, $5 \%$ ammonium sulfate.

\section{Tests for Steroids}

The readiness of the test separates arrangement:

The concentrates were refluxed independently with a heavy drinker arrangement of potassium hydroxide till total saponification. The saponified concentrate was weakened with water and the unsaponifiable issue was separated with diethyl ether. The ethereal concentrate was dissipated and the buildup (unsaponifiable issue) was exposed to the accompanying test by dissolving the buildup in the Chloroform.

\section{Salkowski response}

To $2 \mathrm{ml}$ of concentrate, $2 \mathrm{ml}$ chloroform and $2 \mathrm{ml}$ concentrated $\mathrm{H}_{2} \mathrm{SO}_{4}$ were included. Shook well, regardless of whether the chloroform layer seemed red and the corrosive layer indicated greenish-yellow fluorescence was watched.

\section{Libermann-Burchard test}

Blended $2 \mathrm{ml}$ concentrate in with chloroform. Included 1-2 $\mathrm{ml}$ acidic anhydride and 2 drops fixation $\mathrm{H}_{2} \mathrm{SO}_{4}$ from the side of the test tube watched for first red, at that point blue lastly green shading.

\section{Libermann's test}

Blended $3 \mathrm{ml}$ separate with $3 \mathrm{ml}$ acidic anhydride. Warmed and cooled. Included not many drops concentrated $\mathrm{H}_{2} \mathrm{SO}_{4}$ watched for blue shading. 


\section{Tests for Amino Acids}

\section{Ninhydrin test (General test)}

$3 \mathrm{ml}$ Test Solution what's more, 3 drops 5\% Ninhydrin arrangement were warmed in a bubbling water shower for $10 \mathrm{~min}$. Watched for purple or pale blue shading.

\section{Test for Tyrosine}

Warmed $3 \mathrm{ml}$ Test Solution what's more, 3 drops Million's reagent. Arrangement watched for dim red shading.

\section{Test for tryptophan}

To $3 \mathrm{ml}$ Test Solution included a couple of drops glycoxalic corrosive and concentrated $\mathrm{H}_{2} \mathrm{SO}_{4}$ watched for a rosy violet ring at the intersection of the two layers.

\section{Tests for Glycosides}

Arrangement of test arrangement: The test arrangement was set up by dissolving remove in the liquor or hydroalcoholic arrangement.

\section{Tests for Cardiac Glycosides}

\section{Baljet's test}

A test arrangement watched for yellow to orange shading with sodium picrate.

\section{Bromine water test}

Test arrangement broke down in bromine water giving yellow encourage

\section{Legal's test (For cardenoloids)}

To fluid or alcoholic test arrangement, included $1 \mathrm{ml}$ pyridine and $1 \mathrm{ml}$ sodium nitroprusside watched for pink to red shading.

\section{Test for deoxysugars (KellarKillani test)}

To $2 \mathrm{ml}$ extricate included chilly acidic corrosive, one drop of $5 \% \mathrm{FeCl}_{3}$ and concentrated $\mathrm{H}_{2} \mathrm{SO}_{4}$ watched for rosy dark colored shading at the intersection of the two-fluid and upper layers somewhat blue-green.

\section{Libermann's test (For bufadienolides)}

Blended $3 \mathrm{ml}$ remove with $3 \mathrm{ml}$ acidic anhydride. Warmed and cooled. Included not many drops concentrated $\mathrm{H}_{2} \mathrm{SO}_{4}$ watched for blue shading.

\section{Test for anthraquinone glycosides}

\section{Modified Borntrager's test}

C-glycosides of anthraquinones require progressively exceptional conditions for hydrolysis. Hydrolysis of the medication was completed with $5 \mathrm{ml}$ of weakening $\mathrm{HCl}$ and $5 \mathrm{ml}$ of $5 \%$ arrangement of $\mathrm{FeCl}_{3}$. For hydrolyzed removal technique was done as depicted under Borntrager's test.

\section{Borntrager's test}

Bubbled powdered medication with $5 \mathrm{ml}$ of $10 \%$ sulphuric corrosive for 5 mins. Sifted while hot, cooled the filtrate shaken tenderly with an equivalent volume of benzene.
The benzene layer was isolated and afterward treated with half of its volume arrangement of alkali (10\%). Permitted to isolate it. The ammonical layer obtained rose pink shading because of the nearness of anthraquinones.

\section{Test for Cyanogenetic glycosides}

\section{Grignard's test}

Segments of sodium picrate channel paper were embedded between split plug which was fitted into the neck of the test tube containing a limited quantity of powdered medication in water. Care was practiced that the paper didn't contact the inward side of the test tube. The substance was warmed for thirty minutes. The red shade of the strips showed the nearness of cyanogenetic glycosides.

\section{Tests for Saponin Glycosides}

\section{Foam test}

The medication concentrate or dry powder was shaken vivaciously with water. The relentless froth was watched.

\section{Foaming list}

Gauge $1 \mathrm{gm}$ of finely powdered medication precisely and move to a $500 \mathrm{ml}$ cone-shaped jar containing $100 \mathrm{ml}$ of bubbling water. Keep up a moderate bubbling for $30 \mathrm{~min}$. Cool and channel into a $100 \mathrm{ml}$ volumetric cup and add adequate water to make the volume to $100 \mathrm{ml}$.

Spot the above decoction into 10 stoppered, graduated test-tubes in a progression of progressive bits of 1, 2, 3 up to $10 \mathrm{ml}$ and alter the volume of the fluid in each test tube water to $10 \mathrm{ml}$. Plug the cylinders and shake them vertically for 15 seconds, 2 frequencies/sec. Permit to represent $15 \mathrm{~min}$ and measure the tallness of the froth.

The outcomes assessed as follows:

I) If the tallness of the froth in each cylinder is less than 1 $\mathrm{cm}$, the frothing file is under 100 .

ii) If a stature of froth of $1 \mathrm{~cm}$ is estimated in any cylinder, the volume of the plant material decoction right now is utilized to decide the list. On the off chance that this cylinder is the first or second cylinder in the arrangement, set up a middle of the road weakening likewise to get an increasingly exact outcome.

iii) If the stature of the froth is more than $1 \mathrm{~cm}$ in each cylinder, the frothing file is more than 1000. Right now, the assurance utilizing another arrangement of weakening of the decoction so as to acquire an outcome.

Frothing Index = 100/a

$\mathrm{a}=$ volume in $\mathrm{ml}$ of the decoction utilized for getting ready weakening in the cylinder where frothing to a tallness of 1 $\mathrm{cm}$ is watched.

c) Haemolytic test: Added test answer for one drop of blood put on a glass slide. Haemolytic zone whether showed up was watched. 
Tests for Coumarin Glycosides: Test arrangement when made soluble watched for blue or green fluorescence.

\section{Tests for Alkaloids}

\section{Dragendorff's test}

To 2-3 ml filtrate included scarcely any drops Dragendorff's reagent watched for orange-dark colored accelerate.

\section{Mayer's test}

2-3 $\mathrm{ml}$ filtrate with not many drops Mayer's reagent watched for accelerate.

\section{Hager's test}

2-3 $\mathrm{ml}$ filtrate with Hagers reagent watched for yellow encourage.

\section{Wagner's test}

2-3 $\mathrm{ml}$ filtrate with not many drops of Wagner's reagent watched ruddy darker hasten.

\section{Tests for Flavonoids}

The flavonoids are on the whole fundamentally got from the parent substance called flavone. The flavonoids happen in the free structure just as bound to sugars as glycosides. Therefore, while breaking down flavonoids it is normally better to look at the flavonoids in hydrolyzed plant separates.

The readiness of test arrangement:

i. A limited quantity of concentrate included an equivalent volume of $2 \mathrm{M} \mathrm{HCl}$ and warmed in a test tube for 30 to $40 \mathrm{~min}$. at $100^{\circ} \mathrm{C}$.

ii. The cooled remove was sifted and separated with ethyl acetic acid derivation.

iii. The ethyl acetic acid derivation remove was concentrated to dryness and used to test for flavonoids.

\section{Shinoda test}

To dried powder or concentrate, included $5 \mathrm{ml} 95 \%$ ethanol, scarcely any drops concentrated $\mathrm{HCl}$ and $0.5 \mathrm{~g}$ magnesium turnings. The pink shading was watched. To the little amount of buildup, included lead acetic acid derivation arrangement watched for Yellow shaded accelerate. Extension of a growing proportion of sodium hydroxide to the development of whether showed yellow coloration, which was decolorized after the development of destructive was viewed.

\section{Ferric chloride test}

Test arrangement included hardly any drops of ferric chloride arrangement watched for extraordinary green shading.

\section{Test for Vitamins}

a) Test for Vitamin A: Break down an amount equal to 1015 units in $1 \mathrm{ml}$ chloroform and include $5 \mathrm{ml}$ of antimony trichloride arrangement, transient blue shading is created right away. Test for nutrient C (Ascorbic corrosive):- Dilute $1 \mathrm{ml}$ of $2 \% \mathrm{w} / \mathrm{v}$ arrangement with $5 \mathrm{ml}$ of water and included 1 drop of naturally arranged $5 \% \mathrm{w} / \mathrm{v}$ arrangement of sodium nitroprusside and $2 \mathrm{ml}$ weaken $\mathrm{NaOH}$ arrangement. Included $0.6 \mathrm{ml}$ of hydrochloric corrosive drop wise and mix, the yellow shading turns blue.

\section{Test for Vitamin D:}

Disintegrated an amount equal to around 100 units of Vitamin D, actuating in chloroform and included $10 \mathrm{ml}$ of antimony trichloride arrangement, pinkish-red shading showed up without a moment's delay.

\section{Saponins}

Planning of test arrangement: The test arrangement was set up by dissolving extricate in the water.

\section{Foam test}

Test arrangement when shaken demonstrated the development of froth, which was steady for at any rate 15 $\min$.

\section{Haemolysis test}

$2 \mathrm{ml}$ of $18 \%$ sodium chloride in 2 test tubes were taken, to one test tube added refined water and to other $2 \mathrm{ml}$ test arrangement. A couple of drops of blood were added to both the test tubes. Blended and watched for haemolysis under a magnifying instrument.

\section{Test for steroidal saponins}

The concentrate was hydrolysed with weaken sulphuric corrosive and extricated with chloroform. The chloroform layer was tried for sterols.

\section{Test for triterpenoid and saponins}

The concentrate was hydrolysed with weaken sulphuric corrosive and extricated with chloroform. The chloroform layer was tried for triterpenoids.

\section{Tannins and phenol mixes}

To 2-3 $\mathrm{ml}$ of alcoholic or watery concentrate, included barely any drops of following reagents:

a) $5 \% \mathrm{FeCl} 3$ arrangement: Deep blue-dark shading.

b) Lead acetic acid derivation arrangement: White hasten.

c) Bromine water: Discoloration of bromine water.

d) Acetic corrosive arrangement: Red shading arrangement.

e) Dilute iodine arrangement: Transient red shading.

One drop $\mathrm{NH}_{4} \mathrm{OH}$, an abundance $10 \% \mathrm{AgNO}_{3}$ arrangement. Warmed for $20 \mathrm{~min}$ in a bubbling water shower. The white hasten was watched, at that point, dull silver mirror kept on the mass of the test tube ${ }^{11}$. 


\section{Antioxidant Activity by DPPH Method}

All the extracts were tested for antioxidant activity by DPPH radical scavenging method. Serial dilutions were performed with the stock solution $(10 \mathrm{mg} / \mathrm{ml})$ of all extracts of the plant (Tephrosia purpurea (L.) Pers.). Diluted solutions ( $2 \mathrm{ml}$ each) were mixed with DPPH $(2 \mathrm{ml})$ and allowed to react. The UV absorbance was recorded at $517 \mathrm{~nm}$ and the $\mathrm{RC}_{50}$ value was calculated in $\mu \mathrm{g} / \mathrm{ml}$ for each extract. Ascorbic acid was used as standard antioxidant drug.

The percentage of DPPH scavenging activity was determined by;

\section{$A=\left(A_{0}-A e\right) \times 100 / A_{0}$}

Where, A represents a percentage reduction of the $\mathrm{DPPH}, \mathrm{A}_{0}$ is an initial or blank solution absorbance and $A e$ is an absorbance value for sample concentration in the absence of DPPH solution.

This activity also expressed as the inhibition concentration at $50 \%$ ( $\left.\mathrm{EC}_{50} / \mathrm{IC}_{50} / \mathrm{RC}_{50}\right)$. The $\mathrm{RC}_{50} / \mathrm{EC}_{50}$ value, defined as the amount of the sample sufficient to elicit $50 \%$ reduction of the initial DPPH concentration, was calculated from the linear regression of plots of concentration of test compounds $(\mu \mathrm{g} / \mathrm{mL})$ against the mean percentage of antioxidant activity obtained from the three replicate tests. The free radical scavenging activity of ascorbic acid (Vit C) was also measured under the same condition to serve as positive control ${ }^{12-14}$.

\section{RESULTS}

Table 1: Physical Characteristics of Tephrosia purpurea (L.) Pers.

\begin{tabular}{|c|c|c|}
\hline S. No. & Parameter & $\begin{array}{c}\text { Tephrosia purpurea (L.) } \\
\text { Pers. }\end{array}$ \\
\hline 1. & Loss on Drying & $8.3 \% \mathrm{w} / \mathrm{v}$ \\
\hline 2. & $\begin{array}{c}\text { Ash Value } \\
\text { Total Ash } \\
\text { Acid insoluble ash }\end{array}$ & $\begin{array}{l}6.0 \% \mathrm{w} / \mathrm{w} \\
23 \% \mathrm{w} / \mathrm{w}\end{array}$ \\
\hline 3. & $\begin{array}{c}\text { Extractive Values } \\
\text { Aqueous } \\
\text { Alcohol }\end{array}$ & $\begin{array}{l}7.2 \% \\
8.6 \%\end{array}$ \\
\hline 4. & $\begin{array}{c}\text { Fluorescence } \\
\text { Analysis }\end{array}$ & Blue fluorescence \\
\hline
\end{tabular}

Table 2: Summary of Solvent Used for Extraction \& \% Yield:

\begin{tabular}{|c|c|c|c|c|c|}
\hline S. No. & Drug & $\begin{array}{c}\text { Weight of drug } \\
\text { Taken }\end{array}$ & Solvent & $\begin{array}{c}\text { Volume of } \\
\text { Solvent Taken }\end{array}$ & $\begin{array}{c}\% \text { yields after } \\
\text { Extraction }\end{array}$ \\
\hline 1 & & 900 grams & Petroleum ether & 2.5 lit. & 07.50 \\
\hline 2 & Tephrosia purpurea & 900 grams & Chloroform & 2.5 lit. & 04.50 \\
\hline 3 & (L.) Pers. & 900 grams & Ethanol & 2.5 lit. & 06.00 \\
\hline 4 & & 900 grams & Aqueous & 2.5 lit. & 15.00 \\
\hline
\end{tabular}

Table 3: Chemical Test of Tephrosia purpurea (L.) Pers.

\begin{tabular}{|c|c|c|c|c|c|}
\hline S. No. & Test & Pet. Ether Extract & Chloroform Extract & Alcohol Extract & Aqueous Extract \\
\hline 1 & Test for Carbohydrate & & & & \\
\hline A & Molish Test & + & + & + & + \\
\hline \multirow[t]{3}{*}{ B } & Test for reducing sugars & & & & \\
\hline & Fehling Test & + & + & + & + \\
\hline & Benedict test & + & + & + & + \\
\hline \multirow[t]{2}{*}{$\mathrm{C}$} & Test for Monosaccharide & & & & \\
\hline & Barfoeds Test & - & - & + & + \\
\hline \multirow[t]{2}{*}{$\mathrm{D}$} & Test For Hexose Sugars & & & & \\
\hline & Cobalts Chloride test & - & + & + & + \\
\hline $\mathrm{E}$ & Test for Non- Reducing Sugars & - & + & + & + \\
\hline \multirow[t]{3}{*}{$\mathrm{F}$} & Test for Non- Reducing polysaccharide & & & & \\
\hline & lodine test & + & + & + & + \\
\hline & Tannic acid test & + & + & + & + \\
\hline \multirow[t]{6}{*}{ II } & Test for Proteins & & & & \\
\hline & Biuret test & + & - & + & + \\
\hline & Millon's test & - & - & + & - \\
\hline & Xanthoprotein & - & + & + & - \\
\hline & Test for protins containing Sulphur & - & - & - & - \\
\hline & Precipitation test & + & + & + & + \\
\hline \multirow[t]{2}{*}{ III } & Test for Amino Acid & & & & \\
\hline & Ninhydrin test & + & + & + & + \\
\hline
\end{tabular}




\begin{tabular}{|c|c|c|c|c|c|}
\hline & Test for tyrosin & & - & + & - \\
\hline & Test for tryptophan & - & - & - & - \\
\hline & Test for cysteine & - & - & - & - \\
\hline \multirow[t]{3}{*}{ IV } & Test for Steroids & & & & \\
\hline & Liebermann-Buchard & - & + & - & + \\
\hline & Liebermann reaction & - & + & - & + \\
\hline \multirow[t]{3}{*}{ V } & Test for Terpenoids & & & & \\
\hline & Liebermann-Buchard & - & + & - & + \\
\hline & Liebermann reaction & - & + & - & + \\
\hline VI & Test for Glycosides & & & & \\
\hline \multirow[t]{5}{*}{ A } & Test for Cardiac Glycoside & & & & \\
\hline & Baljet test & - & + & - & + \\
\hline & Legal's test & - & - & - & - \\
\hline & Test for deoxy sugar (Keller killani test) & - & + & - & + \\
\hline & Liebermann's test (Bufadienolides) & - & + & - & + \\
\hline B & Test for Anthraquinone glycoside & - & - & - & - \\
\hline C & Test for Saponin Glycoside & - & + & - & - \\
\hline $\mathrm{D}$ & Test for Coumarin Glycoside & - & - & - & - \\
\hline \multirow[t]{5}{*}{ VII } & Test For Flavonoids & & & & \\
\hline & Ferric chloride test & - & + & - & - \\
\hline & Shinoda test & - & + & - & - \\
\hline & Alkaline reagents & - & + & - & - \\
\hline & Lead acetate test & - & + & - & - \\
\hline VIII & Test for alkaloids & + & - & + & - \\
\hline IX & Test for Tannins \& Phenolic cpd. & - & + & + & + \\
\hline$x$ & Test For Lipids & - & - & + & - \\
\hline
\end{tabular}

\section{Antioxidant Activity by DPPH Method}

Anti-oxidant activity is carried on all the fractions of plant extract to assess their efficacy in tissue healing.

The cell reinforcement action of antioxidative agents has been credited to different systems, for example, the anticipation of chain commencement, an official of progress metal particle impetus, deterioration of peroxides, and avoidance of proceeded with hydrogen deterrent, reductive limit, and radical rummaging. The porcelain dish kept open in vacuum broiler and the example was dried at a temperature $110^{\circ} \mathrm{C}$ for $2 \mathrm{~h}$ until a consistent weight was recorded. The decrease in absorbance of DPPH radical caused by anti-oxidants is due to the reaction between anti-oxidants molecules and radical. Hence, DPPH is usually used as a substance to evaluate anti-oxidant activity. The results as summarized in Table 4 also shows all the extracts of Tephrosia purpurea (L.) Pers. exhibited degree of antioxidant activity.

Table 4: Antioxidant Activity by DPPH method:

\begin{tabular}{|c|c|c|c|}
\hline S. No. & Drug & Extract & $\mathbf{R C}_{\mathbf{5 0}}$ value $(\boldsymbol{\mu g} / \mathbf{m l})$ \\
\hline 1 & & $\begin{array}{c}\text { Petroleum } \\
\text { ether }\end{array}$ & 142.35 \\
\hline 2 & Tephrosia & $\begin{array}{c}\text { Chloroform } \\
\text { purpurea (L.) Pers. }\end{array}$ & 178.53 \\
\hline 3 & & Alcohol & 068.21 \\
\hline 4 & & Aqueous & 156.32 \\
\hline 5 & Ascorbic acid & - & 040.12 \\
\hline
\end{tabular}

\section{DISCUSSION}

Tephrosia purpurea (L.) Pers. is a therapeutic plant from the Family Leguminosae, used as an Indian traditional therapeutic agent. In light of the Phytochemical Investigation or Qualitative examination of Tephrosia purpurea (L.) Pers. the different physical parameters were evaluated. The present examinations were led to assess the $8.3 \% \mathrm{w} / \mathrm{v}$ loss on drying, ash values $(6.0 \% \mathrm{w} / \mathrm{w}$ total ash and $23 \% \mathrm{w} / \mathrm{w}$ acid insoluble ash), extractive values (Aqueous 7.2\%, Alcohol 8.6\%). The Fluorescence Analysis has given blue coloured fluorescence which was observed under the UV radiation lamp to gain more details about the Tephrosia purpurea (L.) Pers. Therefore, chemical tests were performed on 4 various extracts of the T.purpureato estimate the presence of different Phytoconstituents as aqueous extract shows, it contains carbohydrates (Reducing sugars, Monosaccharides, Non-Reducing Sugars), proteins, amino acids(tyrosine \& cysteine), alkaloids, glycosides (cardiac glycoside\& saponins glycoside), flavonoids alkaloids, triterpenoids and lipids, tannins and phenolic compounds.

The antioxidant potential was determined the DPPH method taking ascorbic acid as standard. All the four extracts of the Tephrosia purpurea (L.) Pers. have shown antioxidant efficacy in comparison to the standard drug (Ascorbic acid). The standard ascorbic acid has given the $\mathrm{RC}_{50}$ value for the DPPH method was $040.12 \mu \mathrm{g} / \mathrm{ml}$. The RC50 
estimation of the prescription expels was viewed as chloroform $178.53 \mu \mathrm{g} / \mathrm{ml}$, watery $156.32 \mu \mathrm{g} / \mathrm{ml}$, alcohol $068.21 \mu \mathrm{g} / \mathrm{ml}$, and Petroleum ether $142.35 \mu \mathrm{g} / \mathrm{ml}$, which shows the basic ability of Tephrosia purpurea (L.) Pers. as a cell fortification pro.

\section{CONCLUSION}

The extracts of Tephrosia purpurea (L.) Pers. after concentration is first subjected for preliminary physical and phytochemical investigation to assess the quality of plant material and understand the nature of active constituent's present. After preliminary studies all the 4 extracts were subjected for antioxidant activity by DPPH method to guide us in the selection of extract fraction which will probably has the desired activity. Therefore, Tephrosia purpurea (L.) Pers. can be used as a potential source for the development of an antioxidant agent.

Results of phytochemical investigation revealed the presence of various Phytoconstituents like glycosides, carbohydrates, proteins, amino acids, triterpenoids, cardiac glycosides, flavonoids, lipids, tannins and phenolic compounds.

Acknowledgement: We wish to affirm that there are no known irreconcilable circumstances related to this production and there has been no huge budgetary help for this work could have impacted its result.

\section{REFERENCES}

1. Kokate, C.K., Purohit, A.P., Gokhale, S.B. Text book of Pharmacognosy, fourth ed. Pune. Nirali prakashan, 1996, 58-72. ISBN13: 9788185790152

2. Ram VJ. Herbal preparations as a source of hepatoprotective agents. Drug News Perspect. 14(6), 2001 Aug, 353-63. PMID: 12813598.

3. Chatterjee A, Basak B, Saha M, Dutta U, Mukhopadhyay C, Banerji J, Konda Y, Harigaya Y. Structure and stereochemistry of nardostachysin, a new terpenoid ester constituent of the rhizomes of Nardostachys jatamansi. J Nat Prod. 63(11), 2000 Nov, 1531-3. doi: 10.1021/np990503m. PMID: 11087600.

4. Prabhu V, Karanth KS, Rao A. Effects of Nardostachys jatamansi on biogenic amines and inhibitory amino acids in the rat brain. Planta Med. 60(2), 1994 Apr, 114-7. doi: 10.1055/s-2006-959429. PMID: 8202559.

5. Dixit, V.P., Jain, P., Joshi, S.C. Hypolipidaemic effects of Curcuma longa L \& Nardostachys jatamansi, DC in tritoninduced hyperlipidaemic rats. Indian J Physiol Pharmacol. 32(4), 1988, 299-304. PMID, 3215683.

6. Sarbhoy AK, Varshney JL, Maheshwari ML, Saxena DB. Efficacy of some essential oils and their constituents on few ubiquitous molds. Zentralbl Bakteriol Naturwiss. 133(7-8), 1978, 723-5. doi: 10.1016/s0323-6056(78)80079-2. PMID: 749414.

7. Rucker G, Tautges J, Sieck A, Wenzl H, Graf E. Isolation and pharmacodynamic activity of the sesquiterpene valeranone from Nardostachys jatamansi DC. Arzneimittelforschung, 28(1), 1978, 7-13. PMID: 580202.

8. Rao, V.E., Raju, R.N. Two flavonoids from Tephrosia purpurea. Phytochem. 23(10), 1984, 2339-2342.

9. James A.D. Handbook of Energy Crops. Unpublished. 1983. [available online] http://www.hort.purdue.edu/newcrop/duke_energy Date of visit: 15-10-2013.

10. Ahmad, V. U., Ali, Z., Hussaini, S. R., Iqbal, F., Zahid, M., Abbas, M., \& Saba, N. (1999). Flavonoids of Tephrosia purpurea. Fitoterapia, 70(4), 443-445. https://doi.org/10.1016/\$0367-326X(99)00046-5

11. Saxena VK and Choubey A. 1997. A novel neoflavonoid glycoside from Tephrosia purpurea stem. Fitoterapia. 68(4), 359-360.

12. Choudhary GP. (2007). In vitro antioxidant studies of the ethanolic extract of Tephrosiapurpurea L. Ancient Science of Life 27, 26. Anc Sci Life. 27(1), 2007 Jul-Sep, 26-30. PMCID: PMC3330837, PMID: 22557256

13. Ashokkumar D, Narayana TV, Mazumder UK, Gupta M. Exploration of Diuretic Potential and Electrolyte Excretion of Tephrosia purpurea (Fabaceae) in Rats. Journal of Dietary Supplements 9, 2012, 9-18. DOI: 10.3109/19390211.2011.630715

14. Abayasekara C.L., Rangama B.N.L.D., Panagoda G.J. and Senanayake M.R.D.M., Antimicrobial activity of Tephrosia purpurea (Linn.) Pers. and Mimusops elengi (Linn.) against some clinical bacterial isolates. Journal of the National Science Foundation of Sri Lanka, 37(2), 2009, 139-145. DOI: http://doi.org/10.4038/jnsfsr.v37i2.1071.

Source of Support: None declared.

Conflict of Interest: None declared.

For any question relates to this article, please reach us at: editor@globalresearchonline.net New manuscripts for publication can be submitted at: submit@globalresearchonline.net and submit_ijpsrr@rediffmail.com 